\title{
Improvements of the Dressing Process of Super Abrasive Diamond Grinding Wheels
}

\author{
Janos Kundrák ${ }^{1}$, Vladimir Fedorovich ${ }^{2}$, Angelos P. Markopoulos ${ }^{3}$, Ivan Pyzhov ${ }^{1}$, Natalya Kryukova ${ }^{1}$ \\ ${ }^{1}$ Institute of Manufacturing Science, University of Miskolc, Miskolc, Hungary. E-mail: kundrak@uni-miskolc.hu. \\ ${ }^{2}$ Department of Material Cutting and Cutting Tools, National Technical University "Kharkiv Polytechnic Institute", Khar- \\ kov, Ukraine. \\ ${ }^{3}$ Manufacturing Technology Division, School of Mechanical Engineering, National Technical University of Athens, Ath- \\ ens, Greece.
}

Grinding is the most common finishing process for components that require high accuracy and surface quality. Process performance depends on many factors related to process conditions, workpiece material, grinding fluid but grinding wheel is of special interest. Grinding wheel performance plays a major role on workpiece quality and process efficiency; preparation of the grinding tools and the creation of specific topography of the wheel surface is in direct relation to grinding wheel performance. Questions connected to the possibility to increase production efficiency of diamond dressers owing to technological changes of their production and simplification of preliminary selection of initial samples of diamond are considered. Furthermore, recommendations on improvement of the dressing process of abrasive wheels are made using 3D FEM simulations. The results of theoretical and experimental investigations which cover the development and research on electrochemical dressing of working surface of diamond grinding wheels with metal bonds are also provided.

Keywords: diamond dresser, abrasive ability, wheel dressing, 3D simulation, metal bond of grinding wheels

\section{References}

[1] SPUR, G. (1990). Keramikbearbeitung, Hanser Verlag.

[2] SALJÉ, E., HARBS, H. (1990). Wirkungsweisen und anwendungen von konditionierungsverfahren, Annals of the CIRP, 39, pp. 337-340.

[3] WEGENER, K., HOFFMEISTER, H.-W., KARPUSCHEWSKI, B., KUSTER, F., HAHMANN, W.-C., RABIEY M. (2011). Conditioning and monitoring of grinding wheels, Annals of the CIRP, 60, pp. 757-777.

[4] ZHONG, Z.W., VENKATESH, V.C. (2009). Recent developments in grinding od advanced materials, International Journal of Advanced Manufacturing Technology, 41, pp. 468-480.

[5] MALKIN, S., GUO, C. (2008). Grinding Technology Theory and Applications of Machining with Abrasives, $2^{\text {nd }}$ Edition, Industrial Press.

[6] KLOCKE, F. (2009). Manufacturing Processes 2 Grinding, Honing, Lapping, Springer-Verlag Berlin Heidelberg.

[7] TOENSHOFF, H.K., DENKENA, B. (2013). Basics of Cutting and Abrasive Processes, Springer-Verlag Berlin Heidelberg.

[8] SHEN, J.Y., XU, X.P., LIN, B., XU, Y.S. (2001). Lap-Grinding of $\mathrm{Al}_{2} \mathrm{O}_{3}$ Ceramics Assisted by Water-jet Dressing Metal Bond Diamond Wheel, Key Engineering Materials, 202-203, pp. 171-176.

[9] JODAN, K., MATSUMARU, K., ISHIZAKI, K. (2004). Laser Processing as Surface Conditioning of Grinding Stones for Precision Machining Ceramics, Key Engineering Materials, 264-268, pp. 751-756.

[10] KHANGAR, A., DAHOTRE, N.B., JACKSON, M.J., ROBINSON, G.M. (2006). Laser Dressing of Alumina Grinding Wheels. Journal of Materials Engineering and Performance, 15(2), pp. 178-181.

[11] TAWAKOLI, T., RABIEY, M. (2008). An Innovative Concept and its Effects on Wheel Surface Topography in Dry Grinding by Resin and Vitrified Bond CBN Wheel, Machining Science and Technology, 12(4), pp. 514-528.

[12] OHMORI, H., NAKAGAWA, T. (1990). Mirror Surface Grinding of Silicon Wafers with Electrolytic In-Process Dressing, Annals of CIRP, 39(1), pp. 329-332.

[13] LIM, H.S., FATHIMA, K., KUMAR, A.S., RAHMAN, M. (2002). A Fundamental Study on the Mechanism of Electrolytic In-process Dressing (ELID) Grinding, International Journal of Machine Tools \& Manufacture, 42(8), pp. 935-943.

[14] SALEH, T., BISHWASS, I., RAHMAN, M. (2010). Efficient dressing of the wheel in ELID grinding by controllable voltage with force feed back, International Journal of Advanced Manufacturing Technology, 46, pp. 123130 . 
[15] ZHANG, C., OHMORI, H., LI, W. (2000). Small-hole Machining of Ceramic Material with Electrolytic Intervaldressing (ELID-II) Grinding, Journal of Materials Processing Technology, 105, pp. 284-293.

[16] QIAN, J., LI, W., OHMORI, H. (2000). Precision Internal Grinding with a Metal-Bonded Diamond Grinding Wheel, Journal of Materials Processing Technology, 105, pp. 80-86.

[17] OHMORI, H., KATAHIRA, K., NARUSE, T., UEHARA, Y., NAKAO, A., MITZUTANI, M. (2007). Microscopic Grinding Effects on Fabrication of Ultra-fine Micro Tools, Annals of the CIRP, 56(1), pp. 569-572.

[18] KRAMER, D., REHSTEINER, F., SCHUMACHER, B. (1999). ECD (Electrochemical In-Process Controlled Dressing), a New Method for Grinding of Modern High-performance Cutting Materials to Highest Quality, Annals of the CIRP, 48(1), pp. 265-268.

[19] LEE, E.S. (2000). Surface Characteristics in the Precision grinding of Mn-Zn Ferrite with In-process Electrodischarge Dressing, Journal of Materials Processing Technology, 104, pp. 215-225.

[20] SUZUKI, K., UEMATSU, T., NAKAGAWA, T. (1987). On-machine Trueing/Dressing of Metal Bond Grinding Wheels by Electro-discharge Machining. Annals of the CIRP, 36(1), pp. 115-118.

[21] RHONEY, B.K., SHIH, A.J., SCATTERGOOD, R.O., AKEMON, J.L., GUST, C.J., GRANT, M.B. (2002). Wire Electrical Discharge Machining of Metal Bond Diamond Wheels for Ceramic Grinding, International Journal of Machine Tools \& Manufacture, 42, pp. 1355-1362.

[22] WEINGÄRTNER, E., JAUMANN, S., KUSTER, F., BOCCADORO, M. (2010). Special Wire Guide for Onmachine Wire Electrical Discharge Dressing of Metal Bonded Grinding Wheels, Annals of the CIRP, 59(1), pp. 227-230.

[23] XU, M., LI, D., HU, D., WANG, Z. (2012). Mist-jetting electrical discharge dressing (MEDD) of nonmetal bond diamond grinding wheels using conductive coating, International Journal of Advanced Manufacturing Technology, 63, pp. 955-961.

[24] SCHÖPF, M., BELTRAMI, I., BOCCADORO, M., KRAMER, D., SCHUMACHER, B. (2001). ECDM (Electro Chemical Discharge Machining), a New Method for Trueing and Dressing of Metal Bonded Diamond Grinding Tools. Annals of the CIRP, 50(1), pp. 125-128.

[25] TAMAKI, J., KITAGAWA, T. (1992). Electro Contact Discharge Dressing of Metalbonded Wheel - Truing Efficiency and Grinding Performance, International Journal of the Japan Society for Precision Engineering, 26(4), pp. 284-289.

[26] IKUSE, Y., NONOKAWA, T., KAWABATA, N., KAMO, T., YUZAWA, Y., UNNO, K. (1996). Development of new Ultrasonic Dressing Equipment, International Journal of the Japan Society for Precision Engineering, 30(3), pp. 217-222.

[27] NOMURA, M., WU, Y., KURIYAGAWA, T. (2007). Investigation of Internal Ultrasonically Assisted Grinding of Small Holes; Effect of Ultrasonic Vibration in Truing and Dressing of Small CBN Grinding Wheel, Journal of Mechanical Science and Technology, 21, pp. 1605-1611.

[28] ZHANG, C., SHIN, Y.C. (2002). A Novel Laser-assisted Truing and Dressing Technique for Vitrified CBN Wheels, International Journal of Machine Tools \& Manufacture, 42, pp. 825-835.

[29] WANG, Y., ZHOU, X.J., HU, D.J. (2006). An Experimental Investigation of Dry-electrical Discharge Assisted Truing and Dressing of Metal Bonded Diamond Wheel, International Journal of Machine Tools \& Manufacture, 46(3-4), pp. 333-342.

[30] ZHANG, B., NAKAJIMA, A., KIUCHI, M. (2002). Grinding of $\mathrm{Si}_{3} \mathrm{~N}_{4}$ Ceramic Balls with the Aid of Photo-Catalyst of $\mathrm{TiO}_{2}$, Annals of CIRP, 51(1), pp. 259-262.

[31] SARAVANAPRIYAN, S.N.A., VIJAYARAGHAVAN, L., KRISHNAMURTHY, R. (2003). Performance Evaluation of Treated Grinding Wheels, Materials Science Forum, 437-438, pp. 325-328.

[32] CHEN, W.K. (2005). Loose Abrasive Truing and Dressing of Resin Bond Diamond Cup Wheels for Grinding Fibre Optic Connectors, Journal of Materials Processing Technology, 159, pp. 229-239.

[33] SEMKO, M.F., GRABCHENKO, A.I., KHODOREVSKY, M.G. (1980). Diamond Grinding of Synthetic Superhard Materials, Kharkiv: Vyshcha shkola, pp. 192.

[34] MINKE, E. (1987). Grundlagen der Verschleißausbildung an nicht-rotierenden Abrichtschneiden zum Einsatz an konventionellen Schleifwerkzeugen, PhD-thesis, Universität Bremen.

[35] SHISHKOV, N.Z., SEMENOVA-TYAN-SHANSKAYA, A.S., PIVOVAROV, M.S., GOLENKO, A.I. (1971). Study of the dependence of abrasive ability of ASB diamonds from their microhardness, Diamonds, 8, pp. 1-3. 
[36] ROMANOV, V.F., AVAKIAN, V.V., LAPSHIN, V.A. (1975). Operational characteristics of diamond dressers made of synthetic diamond and other superhard synthetic materials, Diamonds and Superhard Materials, 3, pp. 69.

[37] VERESHCHAGIN, L.F., STERNBERG, L.E., KATZ, M.Y., DOLGOPOLSKAYA, E.F. (1976). Dependence of Abrasive Ability of Synthetic Diamond Units with Microstructure Carbonado (ASPC) on their Density, Diamonds and Superhard Materials, 5, pp. 1-3.

[38] GRABCHENKO, A.I., PYZHOV, I.N. (1982). Features of Contact Interaction of Diamond Wheels when Grinding SHM, in Book: Contact Processes at Large Plastic Deformations, Kharkov: Vishcha Shkola, pp. 33-37.

[39] GRIN, G.I., KOZUB, P.A., MUKHINA, L.V., DROBONOG, I.N. (2006). Methods for Determination of Nickel Coating Quality, Vestnik NTU "KhPI" - Kharkiv: NTU "KPI", 12, pp. 90 - 94.

[40] ZHANG, X.F., LU A.X. (2007). Effects of titanium coating on property of diamond, Transactions of Nonferrous Metals Society of China, 17, pp. 715-719

[41] KUDRYAVTSEV, K.K., STRAKHOVA, G.M., PANCHENKO, M.A. (1976). Influence of Metallization on Oxidation of Synthetic Polycrystalline Materials, Diamonds and Superhard Materials, 5, pp. 3-4.

[42] WANG, Y.H., ZANG, J..B, WANG, H.X., WANG, M.Z. (2001). Effect of Ti coating on the wear stages of diamond in tools, Key Engineering Materials, 202-203, pp. 199-202.

[43] XU, X., TIE, X., WU, H. (2007). The effects of a Ti coating on the performance of metal-bonded diamond composites containing rare earth, International Journal of Refractory Metals \& Hard Materials, 25, $244-249$.

[44] BRINKSMEIER, E., AURICH, J.C. GOVEKAR, E. HEINZEL, C. HOFFMEISTER, H.-W., KLOCKE, F., PETERS J., RENTSCH, R., STEPHENSON, D.J., UHLMANN, E. WEINERT, K., WITTMANN, M. (2006). Advances in Modeling and Simulation of Grinding Processes, Annals of the CIRP, 55(2), pp. 667-696.

[45] COELHO, R. T., DE OLIVERA, J. F. G., DE CAMPOS, G. P. (2001). Experimental and theoretical study of the temperature distribution on diamond dressing tools for precision grinding, $I D R, 3$, pp. 186-193.

[46] ZAGHBANI, I, BOUZUD, W., SAI, K. (2005). A thermo-mechanical coupled FEM model for orthogonal cutting, Proceedings of the 8th CIRP International Workshop on Modeling of Machining Operations, pp. 139-145.

[47] MAMALIS, A.G., GRABCHENKO, A.I., FEDOROVICH, V.A., KUNDRAK, J. (2009). Methodology of 3D simulation of processes in technology of diamond-composite materials. International Journal of Advanced Manufacturing Technology, 43, pp. 1235-1250. 